\title{
Peningkatan kemampuan observasi siswa dengan oral dan written feedback dalam asesmen kinerja pada materi lingkungan
}

\author{
Widamayanti $^{1 *}$, Ana Ratna Wulan ${ }^{2}$, Sariwulan Diana ${ }^{3}$ \\ Fakultas Pendidikan Matematika dan Ilmu Pengetahuan Alam, Universitas Pendidikan Indonesia, \\ Jl. Dr. Setiabudhi No. 229 Bandung 40154 \\ ${ }^{1}$ widamayanti@ui.ac.id *; ${ }^{2}$ anaratnawulan@upi.edu; ${ }^{3}$ sariwulandiana@upi.edu \\ *korespondensi penulis
}

\begin{abstract}
Abstrak
Tujuan penelitian dilakukan untuk meningkatkan kemampuan observasi dengan umpan balik lisan (oral feedback) dan tulisan (written feedback) dalam asesmen kinerja pada pembelajaran pencemaran dan pelestarian lingkungan. Populasi penelitian adalah siswa kelas $\mathrm{X}$ salah satu SMA Negeri di Bandung tahun ajaran 2016/2017. Penelitian ini menggunakan metode quasi experiment dengan desain penelitian mixed method. Sampel penelitian terdiri dari dua kelas, yaitu kelas eksperimen 1 dan kelas eksperimen 2. Kelas eksperimen 1 dalam penelitian ini diberikan penerapan oral feedback, berupa komentar dan pertanyaan secara lisan pada lembar task siswa. Sedangkan untuk kelas eksperimen 2, siswa diberikan penerapan written feedback, berupa komentar dan pertanyaan secara tertulis pada task siswa. Materi pembelajaran yang digunakan dalam penelitian ini adalah materi pencemaran dan pelestarian lingkungan, yang terdiri dari subkonsep pemanasan global dan pencemaran air. Instrumen penelitian yang digunakan, terdiri dari lembar observasi, asesmen kinerja, soal pretest dan posttest, wawancara guru, angket respon siswa, dan catatan lapangan. Berdasarkan analisis data, ditemukan bahwa peningkatan kemampuan observasi siswa kelas eksperimen 1 dan kelas eksperimen 2 berbeda secara signifikan pada pembelajaran pencemaran dan pelestarian lingkungan secara umum.
\end{abstract}

Kata kunci: oral feedback, written feedback, kemampuan observasi siswa, $P O E$, pencemaran dan pelestarian lingkungan.

\begin{abstract}
The aim of research was to to improve student's observation skill with implementation of oral and written feedback as performance assessment in environment learning. In this research, population was $10^{\text {th }}$ grade students in a government senior high school in Bandung in 2016/2017 academic year. This research used quasi experiment method with mixed method design. This study sample consisted of two classes include $1^{\text {st }}$ experimental class and $2^{\text {nd }}$ experimental class. First experimental class has given implementation oral feedback, such as comments and questions orally at student's task. As for the $2^{\text {nd }}$ experimental class, students were given with implementation of written feedback, such as comments and questions that written on student's task. Learning materials was used in this study, consisting of subconcepts global warming and water pollution. The data collected by observation sheets of POE activities, performance assessment, questions of pretest and posttest, teacher's interview, student's responses in questionnaire, and anecdotal record. Data analysis showed that student's observation skill in $1^{\text {st }}$ and $2^{\text {nd }}$ experimental class have different significantly in environment learning generally.
\end{abstract}

Keywords: oral feedback, written feedback, student's observation skill, POE, environment learning. 


\section{PENDAHULUAN}

Kontribusi pembelajaran sains yang rendah terhadap keluluskehidupan warga negara disebabkan karena penggunaan asesmen yang tidak tepat sehingga hanya pengetahuan konsep yang dipersiapkan (National Research Council, 1996). Dengan penggunaan asesmen yang tidak tepat membuat kinerja siswa dalam kegiatan praktikum kurang mendapatkan perhatian (Wulan, 2012). Penggunaan asesmen kinerja di sekolah masih sangat terbatas. Pada umumnya mereka menggunakan asesmen kinerja hanya pada ujian akhir praktikum untuk menentukan kelulusan (Wulan, 2009). Untuk mengaplikasikan pembelajaran yang diperoleh siswa, maka dapat dimulai dari hal yang dekat dan berada di lingkungan sekitar siswa. Dengan begitu, siswa akan mampu mengaplikasikan pengetahuan yang diperolehnya untuk mengatasi permasalahan yang ada di lingkungannya tersebut. Salah satu permasalahan lingkungan yang sedang terjadi saat ini adalah pemanasan global dan pencemaran lingkungan hidup. Pada kenyataannya isu-isu lingkungan berkaitan dengan pencemaran lingkungan masih kurang begitu dipahami dikarenakan adanya kesulitan dan kebingungan yang dihadapi siswa dan guru. Salah satu kesulitan utama yang dirasakan siswa adalah menjelaskan efek rumah kaca dan pemanasan global. Sedangkan, kemampuan aplikasi yang baik dari siswa terhadap materi pencemaran dan pelestarian lingkungan ini tentunya juga harus didukung oleh pemahaman konsep yang baik (Acikalin, 2013). Widyaningrum et al. (2014) mengemukakan bahwa proses pembelajaran tentang pencemaran dan pelestarian lingkungan ini, pada umumnya masih banyak dilaksanakan secara konvensional, yaitu dengan menggunakan metode ceramah. Pernyataan tersebut relevan dengan yang dikemukakan oleh Sulastri dan Rochintaniawati (2009) yang menyatakan bahwa proses pembelajaran biologi monoton dan tidak menarik. Hal tersebut menyebabkan pengembangan keterampilan proses sains menjadi kurang optimal.

Widyaningrum et al. (2014) menyebutkan bahwa salah satu model pembelajaran yang berpotensi untuk melatihkan siswa dalam memecahkan masalah terkait dengan fenomena pencemaran dan pelestarian lingkungan adalah model pembelajaran Predict-Observe-Explain $(P O E)$. Dengan model pembelajaran $P O E$ siswa dituntut untuk aktif dan mengeluarkan sebanyak-banyaknya kemampuan yang mereka miliki dan pada akhirnya mereka merekonstruksi dan mengombinasikan kemampuannya menjadi suatu keterampilan yang utuh (White \& Gustone, 1992). Asesmen yang umumnya dilaksanakan oleh guru-guru di sekolah terhadap konsep pencemaran dan pelestarian lingkungan ini hanya uji kompetensi 
tertulis/ulangan di akhir seluruh konsep atau lebih dikenal dengan asesmen sumatif. Jika asesmen yang dilakukan hanya terbatas pada asesmen sumatif saja, maka sesuai dengan fungsi asesmen sumatif tersebut yaitu hanya menentukan letak kemampuan siswa berdasarkan tujuan instruksional yang harus dicapai oleh siswa. Berdasarkan hal tersebut, maka sangat sedikit umpan balik (feedback) yang akan diperoleh siswa serta kurangnya pemantauan akan pemahaman siswa secara periodik (Sriyati, 2011). Morris dan Chikwa (2016) menyatakan bahwa siswa tidak selalu memanfaatkan umpan balik. Misalnya, guru mengeluh tentang siswa yang tidak memanfaatkan umpan balik yang mereka terima. Siswa mungkin gagal untuk menggunakan umpan balik karena umpan balik yang diterima terlambat untuk dianggap berguna atau siswa menemukan umpan balik atau komentar yang diberikan guru sulit untuk dimengerti. Selain itu, saran atau komentar yang kurang jelas juga menyebabkan siswa tidak mampu memperbaiki hasil pekerjaannya. Guru memiliki peranan yang penting untuk memastikan bahwa setiap umpan balik diberikan dapat mendorong siswa untuk memiliki kesempatan belajar yang lebih baik di pembelajaran selanjutnya. Pemberian umpan balik terhadap siswa siswa diperlukan untuk meningkatkan kemampuan observasi siswa dengan memberikan komentar khusus dan saran spesifik terhadap kesalahan yang dilakukan.

\section{METODE}

Metode penelitian yang digunakan adalah quasi experiment dengan desain penelitiannya adalah mixed method. Penelitian dilakukan di salah satu SMA Negeri di Kota Bandung. Partisipan penelitian adalah siswa kelas X IPA 3 sebagai kelas eksperimen 1 yang diberi penerapan oral feedback dan kelas X IPA 4 sebagai kelas eksperimen 2 yang diberi penerapan written feedback. Siswa yang berpartisipasi dalam penelitian sebanyak 30 siswa dari kelas eksperimen 1 maupun kelas eksperimen 2. Teknik pengambilan sampel yang digunakan yaitu cluster random sampling.

Instrumen yang digunakan sebagai alat untuk menjaring data dalam penelitian ini berupa lembar observasi beserta rubrik penilaian kegiatan $P O E$, asesmen kinerja, soal pretest dan posttest, angket respon siswa, dan wawancara guru. Teknik pengumpulan data yang dilakukan pada penelitian terdiri atas identifikasi kemampuan observasi siswa melalui lembar observasi dan asesmen kinerja (task dan rubrik). Pengumpulan data juga dilakukan dengan tes melalui pretest dan posttest, identifikasi respon siswa dengan pengisian angket dan respon guru melalui wawancara, serta dokumentasi penelitian berupa catatan lapangan. Analisis data 
hasil penelitian dilakukan secara kuantitatif dengan hasil kemampuan observasi siswa sebagai data utama penelitian. Hasil kemampuan prediksi dan eksplanasi siswa, pretest serta posttest merupakan data pendukung dalam penelitian ini. Data tersebut dianalisis menggunakan Software Statistical Package for The Social Science (SPSS) 20.0 for Windows. Data berupa tanggapan siswa terhadap penerapan oral dan written feedback dianalisis menggunakan skala Likert-4.

\section{HASIL DAN PEMBAHASAN}

Hasil penelitian diperoleh skor kemampuan observasi dari siswa kelas eksperimen 1 dan kelas eksperimen 2 merupakan data penelitian utama. Kelas eksperimen 1 yaitu kelas yang diberi penerapan oral feedback, sedangkan kelas eksperimen 2 yang diberi penerapan written feedback. Untuk mengidentifikasi kemampuan observasi dari siswa, digunakan task (lembar kegiatan siswa dengan rubrik penilaian) beserta lembar observasi siswa. Task yang digunakan dalam pembelajaran lingkungan ini, terdiri dari dua task yaitu untuk subkonsep pemanasan global dan pencemaran air. Kemampuan observasi siswa pada subkonsep pemanasan global sebagai kemampuan observasi awal siswa, sedangkan pada subkonsep pencemaran air sebagai kemampuan observasi akhir siswa. Untuk mengungkap peningkatan kemampuan observasi siswa pada pembelajaran pencemaran dan pelestarian lingkungan hidup setelah diterapkan oral feedback pada kelas eksperimen 1 dan written feedback pada kelas eksperimen 2, maka data kemampuan observasi siswa dianalisis dengan menggunakan uji indeks gain.

Tabel 1. Perbandingan rata-rata persentase kemampuan observasi awal, observasi akhir, dan $N$-gain pada pembelajaran lingkungan

\begin{tabular}{ccc}
\hline Komponen Peninjau & Kelas Eksperimen & Kelas Eksperimen \\
& $\mathbf{1}$ & $\mathbf{2}$ \\
\hline Jumlah siswa & 30 & 30 \\
\hline $\bar{x}$ Kemampuan Observasi Awal & $67,4 \%^{\mathrm{a}}$ & $68,9 \%^{\mathrm{a}}$ \\
\hline $\bar{x}$ Kemampuan Observasi Akhir & $86,1 \%^{\mathrm{b}}$ & $91,5 \%^{\mathrm{c}}$ \\
\hline $\bar{x}$ Nilai $N$-gain Kemampuan Observasi & 0,56 & 0,71 \\
\hline \multicolumn{4}{c}{ Kategori } & Sedang & Tinggi \\
\hline a & & \\
${ }^{\mathrm{b}}$ dan ${ }^{\mathrm{c}}$ Kedua data tidak terdapat perbedaan signifikan data terdapat perbedaan signifikan & & \\
Rata-rata persentase kemampuan observasi akhir setelah diberi penerapan umpan balik \\
yang paling tinggi diperoleh kelas eksperimen 2 yaitu sebesar 91,5\%. Selisih perolehan rata-
\end{tabular}


rata persentase kemampuan observasi akhir antara siswa kelas eksperimen 1 dan kelas eksperimen 2 sebesar 5,4\%. Sejauh ini dapat terlihat bahwa kemampuan observasi akhir siswa setelah diberi penerapan umpan balik pada kelas eksperimen 1 termasuk ke dalam kategori baik, sedangkan pada kelas eksperimen 2 termasuk ke dalam kategori sangat baik. Selanjutnya dilakukan analisis $N$-gain yang bertujuan untuk mengungkap peningkatan kemampuan observasi yang terjadi pada pembelajaran pencemaran dan pelestarian lingkungan antara siswa kelas eksperimen 1 dengan kelas eksperimen 2. Perbandingan perolehan nilai $\mathrm{N}$-gain kemampuan observasi antara siswa kelas eksperimen 1 dan kelas eksperimen 2 disajikan pada Gambar 1.

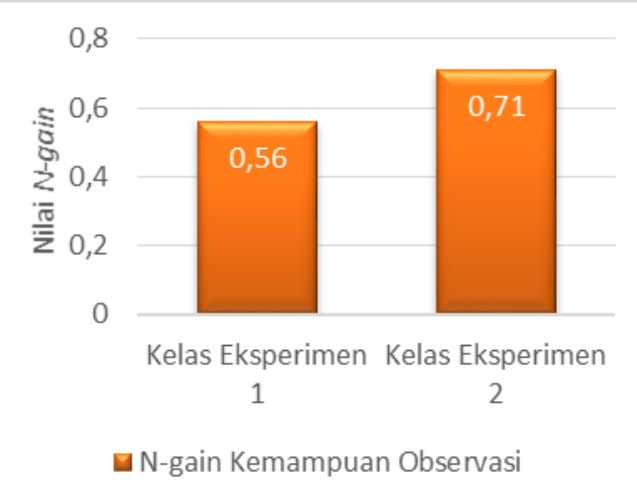

Gambar 1 Perbandingan nilai $N$-gain kemampuan observasi kelas eksperimen 1 dan kelas eksperimen 2 pada pembelajaran lingkungan

Pada pembelajaran lingkungan, perolehan nilai rata-rata $N$-gain kemampuan observasi siswa kelas eksperimen 2 lebih tinggi dibandingkan dengan kelas eksperimen 1. Selisih ratarata nilai $N$-gain dari kedua kelas tersebut hanya sebesar 0,15 . Rata-rata nilai $N$-gain yang diperoleh kelas eksperimen 1 termasuk kategori sedang, sedangkan kelas eksperimen 2 termasuk kategori tinggi. Hasil tersebut menunjukkan bahwa peningkatan kemampuan observasi siswa pada kelas eksperimen 2 lebih besar apabila dibandingkan dengan kelas eksperimen 1. 


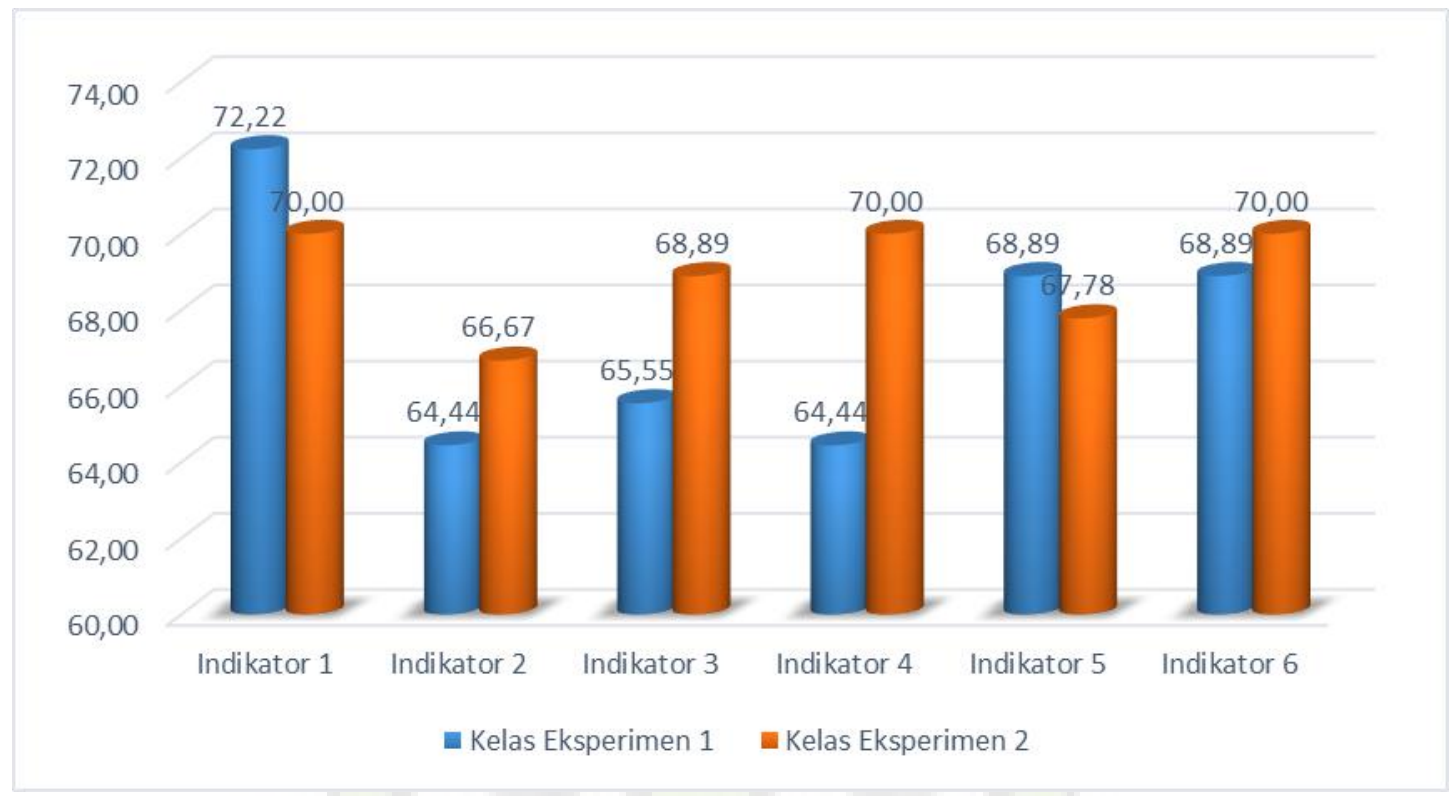

Gambar 2. Rata-rata persentase setiap indikator kemampuan observasi awal siswa pada subkonsep pemanasan global

Keterangan indikator:

1: Melakukan praktikum pemanasan global sesuai dengan langkah kerja yang berurutan.

2: Memperhatikan keselamatan kerja dan kebersihan dalam penggunaan alat dan bahan selama praktikum pemanasan global berlangsung.

3: Mengamati praktikum peristiwa pemanasan global terhadap suhu dan tinggi permukaan air awal dan akhir secara langsung.

4: Melakukan pengamatan secara berkala setiap 5 menit sekali terhadap suhu dan tinggi permukaan air awal dan akhir selama 15 menit.

5: Menggunakan alat indera yang sesuai dalam melakukan pengamatan suhu dan tinggi permukaan air awal dan akhir.

6: Mencatat data hasil observasi secara berkala dan lengkap setiap 5 menit sekali dan sesuai fakta dari suhu dan tinggi permukaan air.

Berdasarkan Gambar 2, persentase semua indikator pada kelas eksperimen 1 dan kelas eksperimen 2 termasuk kategori cukup. Dalam pembelajaran subkonsep pemanasan global kelas eksperimen 1 memiliki dua indikator yang persentasenya lebih tinggi dibandingkan dengan kelas eksperimen 2, yaitu indikator 1 dan 5. Pada indikator 1, sebagian siswa kelas eksperimen 1 dan kelas eksperimen 2 telah melakukan praktikum pemanasan global dengan langkah kerja yang masih kurang tepat, namun alat dan bahan masih sudah tepat digunakan. Hanya sebagian kecil siswa kelas eksperimen 1 yang sudah melakukan praktikum dengan langkah kerja yang tepat dan penggunaan alat dan bahan yang tepat. Pada indikator 5, hanya 
sebagian siswa kelas eksperimen 1 dan kelas eksperimen 2 yang menggunakan alat indera penglihatan dalam pengamatan suhu dan tinggi permukaan air pada diorama. Sebagian siswa lainnya tidak menggunaka alat indera penglihatan, hanya mengandalkan bertanya kepada teman yang dalam kolompoknya saja. Masing-masing indikator pada kedua kelas eksperimen tersebut memiliki persentase dengan selisih sebesar 2,22\% dan 1,11\%.

Empat indikator lainnya, yaitu indikator 2, 3, 4, dan 6 berhasil diungguli oleh kelas eksperimen 2. Pada indikator 2, kelas eksperimen 1 dan kelas eksperimen 2 masih kurang dalam memperhatikan kebersihan sekitar diorama selama praktikum berlangsung. Pada saat pengisian diorama banyak air yang tumpah pada meja praktikum namun tidak langsung dibersihkan sehingga menyebabkan meja dan lantai praktikum berair. Hanya tiga orang siswa kelas eksperimen 2 dengan sigap membersihkan air yang tumpah. Pada indikator 3, sebagian siswa kelas eksperimen 1 dan 2 melakukan pengamatan awal terhadap suhu dan tinggi permukaan air pada diorama A dan B saja. Beberapa siswa kelas eksperimen 2 melakukan pengamatan awal dan akhir terhadap suhu dan tinggi permukaan air pada diorama $\mathrm{A}$ dan $\mathrm{B}$. Pada indikator 4, sebagian siswa kelas eksperimen 1 dan kelas eksperimen 2 melakukan pengamatan secara berkala setiap 5 menit sekali selama 10 menit dari yang seharusnya 15 menit. Beberapa siswa kelas eksperimen 2 yang melakukan pengamatan selama 15 menit. Pada indikator 6, sebagian siswa kelas eksperimen 1 dan kelas eksperimen 2 telah mencatat hasil observasi secara berkala dan lengkap setiap 5 menit sekali terhadap suhu dan tinggi permukaan air. Beberapa siswa kelas eksperimen 1 dan kelas eksperimen 2 telah mencatat hasil observasi secara berkala dan lengkap selama 15 menit pada tabel pengamatan LKS praktikum pemanasan global. Hasil observasi siswa tercatat bahwa pada diorama B yang diberi $\mathrm{CO}_{2}$ semakin lama suhu dan permukaan air semakin tinggi. Hal ini menunjukkan bahwa peningkatan kadar $\mathrm{CO}_{2}$ membuat suhu pada diorama meningkat. Suhu yang semakin meningkat membuat potongan batu es mencair, sehingga tinggi permukaan air pada diorama juga semakin naik. Peristiwa ini sesuai dengan yang dikemukakan Campbell \& Reece (2008) bahwa peningkatan kadar $\mathrm{CO}_{2}$, mampu meningkatkan suhu di permukaan bumi, baik perubahan rata-rata suhu global maupun perubahan kontras antara suhu di ekuator dengan suhu di kutub mengubah jumlah panas bumi. Peningkatan kadar $\mathrm{CO}_{2}$ dapat menyebabkan perubahan iklim di bumi. Peningkatan ini merupakan akibat aktivitas manusia seperti deforestasi, pembuangan material, dan pembakaran bahan bakar fosil (Cross \& Bowden, 2009). 


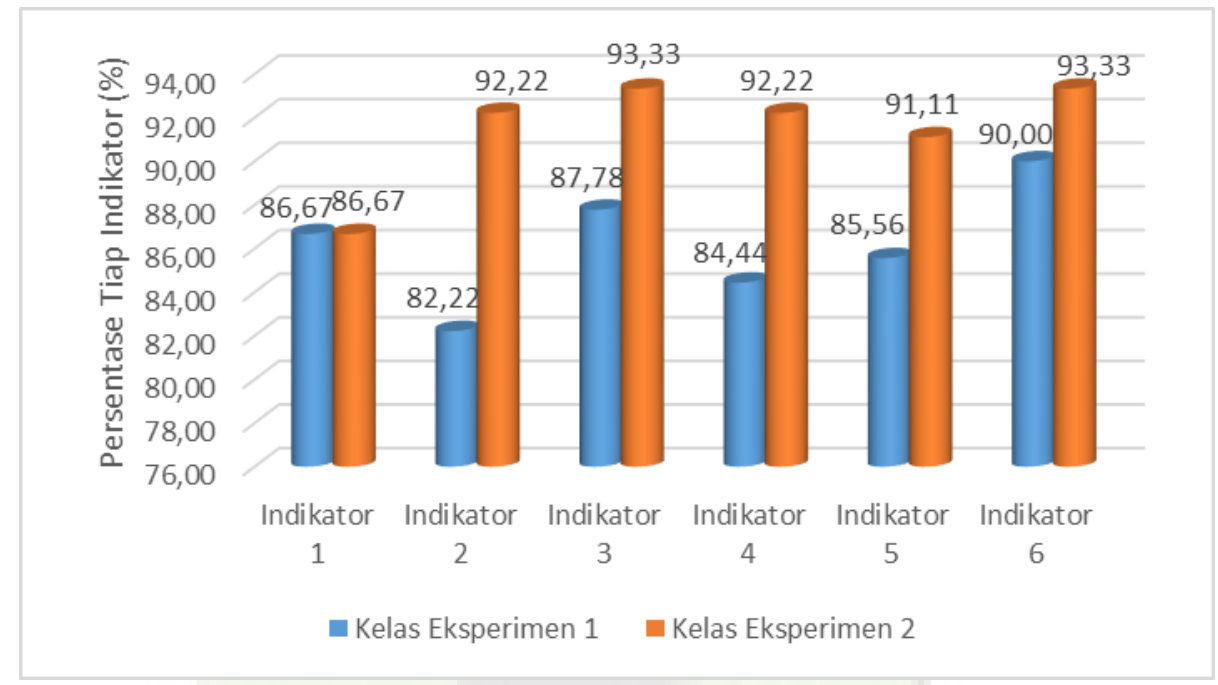

Gambar 3 Rata-rata persentase setiap indikator kemampuan observasi siswa pada subkonsep pencemaran air

Keterangan indikator:

1 : Melakukan praktikum pencemaran air sesuai dengan langkah kerja yang berurutan.

2 : Memperhatikan keselamatan kerja dan kebersihan dalam penggunaan alat dan bahan selama praktikum pencemaran air berlangsung.

3: Mengamati praktikum pencemaran air terhadap keadaan awal dan akhir ikan pada ketiga bejana secara langsung.

4 : Melakukan pengamatan secara berkala dan lengkap setiap 5 menit sekali terhadap keadaan awal dan akhir ikan selama 20 menit.

5 : Menggunakan alat indera yang sesuai dalam melakukan pengamatan keadaan awal dan akhir ikan.

6 : Mencatat data hasil observasi secara berkala dan lengkap setiap 5 menit sekali dan sesuai fakta dari keadaan awal dan akhir ikan.

Berdasarkan Gambar 3, kelas eksperimen 1 memiliki persentase dari satu indikator yang termasuk dalam kategori sangat baik, yaitu indikator 6, sedangkan lima indikator lainnya termasuk kategori sangat baik. Untuk kelas eksperimen 2, persentase dari lima indikator kemampuan observasi termasuk dalam kategori sangat baik, hanya satu indikator yang termasuk kategori baik, yaitu indikator 1. Dalam pembelajaran subkonsep pencemaran air terdapat satu indikator yang persentasenya sama antar kelas eksperimen 1 dan kelas 
eksperimen 2 telah melakukan praktikum pencemaran air yang sesuai dengan langkah kerja dan penggunaan alat dan bahan sudah tepat.

Lima indikator lainnya, yaitu indikator $2,3,4,5$, dan 6, persentase tertinggi berhasil dicapai kelas eksperimen 2. Pada indikator 2, hampir seluruh siswa kelas eksperimen 2 memperhatikan keselamatan kerja dan kebersihan bejana plastik dan air yang digunakan pada saat praktikum pencemaran air. Hanya sebagian siswa kelas eksperimen 1 yang memperhatikan indikator penilaian ini. Pada indikator 3, 4, dan 5, hampir seluruh siswa kelas eksperimen 2 menggunakan alat indera penglihatan terhadap pengamatan keadaan awal dan akhir ikan mas pada masing-masing bejana setiap 5 menit sekali selama 15 menit. Pada kelas eksperimen 1, beberapa siswa melakukan pengamatan terhadap keadaan awal atau akhir ikan mas pada tiap bejana selama 10 menit saja. Beberapa siswa tersebut tidak melakukan pengamatan secara langung, hanya mengandalkan teman sekelompoknya dalam pengamatan. Dengan dilakukannya pengamatan secara berkala dan menyeluruh, pada indikator 6 hampir seluruh siswa kelas eksperimen 2 dapat mencatat setiap hasil observasinya pada tabel pengamatan LKS praktikum pencemaran air sesuai dengan fakta. Beberapa siswa kelas eksperimen 1 tidak mencatat hasil observasi secara berkala dan lengkap dikarenakan hanya menunggu jawaban dari teman sekolompoknya. Pada pengamatan keadaan awal dan akhir ikan mas, semua ikan mas pada bejana B dengan larutan detergen cair dan bejana $\mathrm{C}$ dengan larutan detergen ramah lingkungan mengalami kematian, sedangkan pada bejana A dengan air jernih semua ikan mas masih hidup dan bergerak lincah. Hal tersebut terjadi dikarenakan air pada kedua bejana tersebut tercemar oleh kandungan zat kimia pada detergen. Air yang tercemar membuat aktivitas organisme yang hidup di air menjadi terganggu bahkan mengalami kematian, khususnya ikan mas. Ikan mas mengalami kematian dibuktikan dengan tidak adanya gerakan operkulum dan tubuhnya mengapung pada permukaan air. Hal tersebut sesuai dengan yang diungkapkan oleh Larsson et al. (1976) bahwa ikan dapat menunjukkan reaksi terhadap perubahan fisik air maupun terhadap adanya senyawa pencemar dengan gerakan operkulum yang semakin meningkat, sehingga akhirnya tidak bergerak lagi dan akhirnya mengalami kematian. Sumber kontaminan pencemaran air berasal dari limbah industri dan tempat pembuangan akhir sampah (TPA), atau aktivitas manusia (Trefi \& Hazen, 2010). 


\section{SIMPULAN}

Hasil penelitian menunjukkan bahwa oral dan written feedback pada asesmen kinerja dapat meningkatkan kemampuan observasi pada siswa pada materi pencemaran dan pelestarian lingkungan. Oral dan written feedback memfasilitasi proses asesmen kinerja dan memudahkan proses pengukuran kemampuan observasi siswa selama praktikum. Kemampuan observasi akhir siswa setelah diterapkannya oral dan written feedback pada kelas oral feedback dan kelas written feedback mengalami peningkatan pada pembelajaran pencemaran dan pelestarian lingkungan.

Peningkatan kemampuan observasi siswa yang lebih tinggi setelah diterapkannya written feedback. Peningkatan kemampuan observasi siswa didukung dengan adanya perbedaan secara signifikan antara kelas eksperimen oral feedback dan kelas written feedback. Siswa menyatakan dengan adanya penerapan oral dan written feedback mampu meningkatkan motivasi, ketertarikan, kemandirian, dan keaktifan siswa dalam dalam pembelajaran dan memperbaiki kinerjanya dalam pembelajaran.

Kelebihan oral feedback sebagai asesmen kinerja adalah dapat langsung mengarahkan dan memperbaiki hasil kerja siswa dalam praktikum, menjadi reward bagi siswa, dan mengembangkan aspek kognitif dan keterampilan siswa. Adapun kekurangannya adalah hanya terfokus dalam praktis pelaksanaan kegiatan praktikum, siswa mudah lupa dengan saran dan pertanyaan yang diberikan guru, dan waktu pembelajaran yang lebih lama untuk menjangkau seluruh siswa. Kelebihan written feedback di antaranya adalah terjangkaunya masing-masing siswa sesuai dengan kemampuannya, saran dan komentar dijadikan acuan untuk kegiatan pembelajaran selanjutnya, dan memicu tantangan dan persaingan dalam kelas. Kekurangannya adalah komentar dan pertanyaan tertulis pada task menjadi keluhan siswa, terfokus pada konten task, dan terfokus memperbaiki yang tertulis sehingga melupakan memperbaiki kemampuan alamiah siswa.

\section{REFERENSI}

Acikalin, F.S. 2013. Middle School Student's Conception of Environmental Issues. International Journal of New Trends in Arts, Sports and Science Education. 2 (4): 23 27.

Black, P. \& William, D. 1998. Assessment and Classroom Learning. Assessment in Education. 5 (1) : 7-74.

Black, P., Harrison, C., Lee, C., Marshall, B., \& William, D. 2004. Working Inside The Black Box: Assessment for Learning in the Classroom. Phi Delta Kappan. 86 (1): 8-21. 
Campbell, N. A. \& Reece, J. B. 2008. Biologi Edisi Kedelapan Jilid 3. Jakarta: Erlangga.

Carol, B. 2002. The Concept of Formative Assessment. Practical Assessment, Research, and Evaluation. 8 (9): 1-8.

Gioka, O. 2010. Assessment for Learning in Biology Lessons. Journal of Biological Education. 41 (3): 113-116.

Higgins, R., Hartley, P., \& Skelton, A. 2002. The Conscientious Consumer: Reconsidering the role of assessment feedback in student learning. Studies in Higher Education. 27 (1): 53-64.

Ivanic, R., Clark, R. \& Rimmershaw, R. 2000. What am I supposed to make of this? The messages conveyed to students by tutors' written comments, in: M.R. Lea and B. Stierer, (Eds) Student Writing in Higher Education: New Contexts. Buckingham: Open University Press.

Lizzio, A., \& Wilson, K. 2008. Feedback on assessment: students' perceptions of quality and effectiveness. Assessment and Evaluation in Higher Education. 33 (3): 263-275.

Morris, C. \& Chikwa, G. 2016. Audio versus written feedback: exploring learners' preference and the impact of feedback format on students' academic performance. Active Learning in Higher Education. 17 (2): 125-137.

National Research Council. 1996. National Science Education Standards. Washington: National Academy Press.

Northen Illinois University. 2010. Formative and Summative Assessment. Faculty Development and Instructional Design Center facdev@ niu.edu, 815.753.0595.

Rustaman, N.Y., dkk. 2005. Strategi Belajar Mengajar Biologi. Malang: UM Press.

Sadler, D. 1989. Formative assessment and the design of instructional systems. Instructional Science. 18: 119-144.

Sriyati, S. 2007. Peran Asesmen Formatif dalam Membentuk Habits of Mind Mahasiswa. Disertasi tidak diterbitkan. Bandung: Pascasarjana Universitas Pendidikan Indonesia.

Stiggins, R.J. 1994. Student-centered Classroom Assessment. New York: Macmillan Publishing Company.

Sulastri, Y. \& Rochintaniawati, D. 2009. Pengaruh Penggunaan Pembelajaran Kooperatif Tipe Jigsaw Dalam Pembelajaran Biologi Di SMPN 2 Cimalaka. Jurnal Pengajaran MIPA. 13 (1): 15-22.

Trefil, J dan Robert, M.H. 2013. Sciences Seventh Edition. Singapore: John Wiley and Sons.

Wahyuni , S. E., Sudarisman, S., \& Karyanto, P. 2013. Pembelajaran biologi model poe (prediction, observation, explanation) melalui laboratorium riil dan laboratorium virtuil ditinjau dari aktivitas belajar dan kemampuan berpikir abstrak. Jurnal Materi dan Pembelajaran Fisika. 2 (3): 40-49.

White, R. \& Gunstone, R. 1992. Probing Understanding. London: The Falmer Press.

Wulan, A.R. 2009. Kemampuan Calon Guru Biologi dalam Menyusun Rubrik Analitis pada Asesmen Kinerja Pembelajaran. Prosiding Seminar Nasional Penelitian, Pendidikan $\&$ Penerapan MIPA, Fakultas MIPA, Universitas Negeri Yogyakarta.

Wulan, A.R. 2012. Skenario Baru Bagi Implementasi Asesmen Kinerja pada Pembelajaran Sains di Indonesia. Bandung: Universitas Pendidikan Indonesia.

Xingcun, L. 2004. The role of biology in environmental education. Chinese Education and Society. 37 (4): 68-70. 